\title{
Pertumbuhan ikan kuwe putih Caranx sexfasciatus di karamba jaring apung yang diberi pakan rucah dengan bahan tambahan yang berbeda
}

\section{(The growth of Caranx sexfasciatus in floating net cage fed with trash feed with different supplementation)}

\author{
Grace F. Mansauda, Julius Sampekalo, Cyska Lumenta
}

\begin{abstract}
The use of trash fish ( Treatment A ), trash fish + cassava( Treatment B), pellets+ trash fish ( Treatment C ) and a mixture of trash fish + cassava + pellets ( Treatment D ) as feed had been conducted to evaluate its effect on growth of Caranx sexfasciatus. This research was carried out inTelengen Bay waters, Central Tabukan District, Sangihe Islands Regency. Fish with weighing 60,9 -62,9 g were distributed in 12 net cages measuring $3 \times 1 \times 1 \mathrm{~m}$ with the density of 5 fish each. Fish were fed three times a day for seven weeks. Fish weight was measured every week. At the end of experiment, the individual weight of fish ranged from 168,7 to 222,8 $\mathrm{g}$ in with the highest average weigth gain was achieved in treatment A namely $222.8 \mathrm{~g}$ (354.2\%)), followed by treatment C $178.0 \mathrm{~g}(286.6 \%)$ treatment D $170.08 \mathrm{~g}(280.5 \%)$, and treatment B as much as $168.7 \mathrm{~g}$ (274.3\%). Statistical analysis displayed that weight gain of fish in treatment A was significantly different as compared to that of treatments B, C, and D. There was no significant differencesbetween treatment B, C, and D. Food conversion ratio of treatment A was significantly different compared to other treatments. Food conversion ratio of treatment A was 2.80 , B 4.25, C 3.70, D 3.88. as conclusion, the use of trash fish without supplementaion with others ingradients resulted in the highest absolute and relatif growth of fish and the lowest food conversion ratio of 2.80 as compared to other treatments.
\end{abstract}

Keywords: Caranx sexfasciatus, weight gain, food conversion ratio, floting net cage.

\section{PENDAHULUAN}

Usaha budidaya pantai sistem kurungan jaring apung (KJA) sudah cukup lama dikenal oleh masyarakat Kabupaten Kepulauan Sangihe (Aziz, 1988). Saat ini sudah mulai terpusat di Teluk Talengen. Salah satu komoditi penting yang sementara dibudidayakan adalah ikan Kuwe (Caranx sp) oleh masyarakat setempat.
Menurut Irianto $d k k$ (2002), dibandingkan dengan jenis-jenis ikan lainnya, ikan kuwe (Caranx spp.) merupakan salah satu jenis ikan karang yang sangat potensial untuk dikembangkan karena mempunyai beberapa keunggulan komparatif antara lain mampu hidup dalam kondisi kepadatan yang tinggi (150 ekor $/ \mathrm{m}^{2}$ ), mempunyai laju pertumbuhan tinggi, sangat tanggap terhadap penambahan 
pakan dari ikan rucah, konversi pakan cukup efisien dan digemari konsumen.

Ketersediaan ikan rucah sebagai pakan utama ikan Kuwe selalu berfluktuasi menurut musim penangkapan baik jumlah maupun jenisnya (Lutfillah, 1988). Pada saat tertentu ketersediaan pakan ini sedikit sehingga menjadi masalah besar dalam pemeliharaannya. Upaya alternatif yang dapat dilakukan adalah menambahkan beberapa suplemen pakan pada ikan rucah, supaya jumlah pakan yang ada dapat memenuhi kebutuhan makanan ikan Kuwe peliharaan, antara lain ubi kayu dan pelet komersial.

Biaya pengadaan pakan bisa mencapai $\pm 60 \%$ dari total biaya produksi, maka sebaiknya dapat memanfaatkan bahan baku lokal yang tersedia atau hasil sampingan/limbah dari usaha pertanian, perikanan maupun peternakan yang kandungan nutrisinya masih memenuhi nilai kebutuhan gizi yang meliputi kandungan protein, lemak, karbohidrat, vitamin dan mineral (Mujiman, 1984). Padahal ketersediaan pakan yang cukup, tepat waktu, dan bergizi merupakan faktor yang penting dalam usaha budidaya ikan (Anonim, 2009). Apabila pakan yang diberikan tidak sesuai dengan kebutuhan ikan yang dibudidaya, maka akan menyebabkan pertumbuhan dan produksi ikan berkurang.

Pengetahuan tentang Nilai Ubah Pakan atau Food Conversion Ratio yang sangat berguna untuk menentukan kebutuhan pakan yang akan digunakan dalam proses budidaya, sehingga perhitungan biaya untuk pakan tidak berlebihan (boros) atau bahkan kekurangan. Hal ini sangat bermanfaat bagi pelaku usaha budidaya yang akan menanamkan modalnya untuk usaha budidaya suatu komoditi laut (Yudha, 2003).

Adapun tujuan penelitian ini adalah mengkaji pertumbuhan mutlak dan nisbi ikan kuwe putih Caranx sexfasciatus yang diberi pakan tambahan berbeda dan untuk mengetahui nilai ubah pakan dari setiap pakan tambahan bahan yang diberikan.

\section{BAHAN DAN METODE}

\section{Tempat dan Waktu Penelitian}

Penelitian telah dilaksanakan di perairan Teluk Talengen, Kecamatan Tabukan Tengah, Kabupaten Kepulauan Sangihe, tepatnya di lokasi KJA/budidaya ikan kuwe milik Politeknik Negeri Nusa Utara Tahuna. Penelitian dilaksanakan selama 7 minggu yaitu dari tanggal 9 Mei 3 Juli 2013.

\section{Tahapan Penelitian}

Ikan kuwe putih sebanyak 60 ekor dengan berat 57-70 g/ekor digunakan sebagai ikan uji (Gambar 1). Ikan tersebut ditebar masing-masing sebanyak 5 ekor ke dalam 12 petak jaring dimana setiap petak berukuran 3x1x1 m (Gambar 2). Kemudian ikan uji diberi 4 perlakuan berupa pakan dengan kandungan bahan yang berbeda selama 7 minggu.

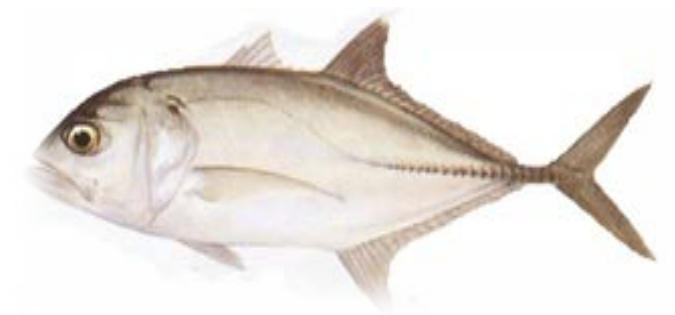

Gambar 1. Ikan Kuwe Putih Caranx sexfasciatus (Randall, dkk., 1997) 


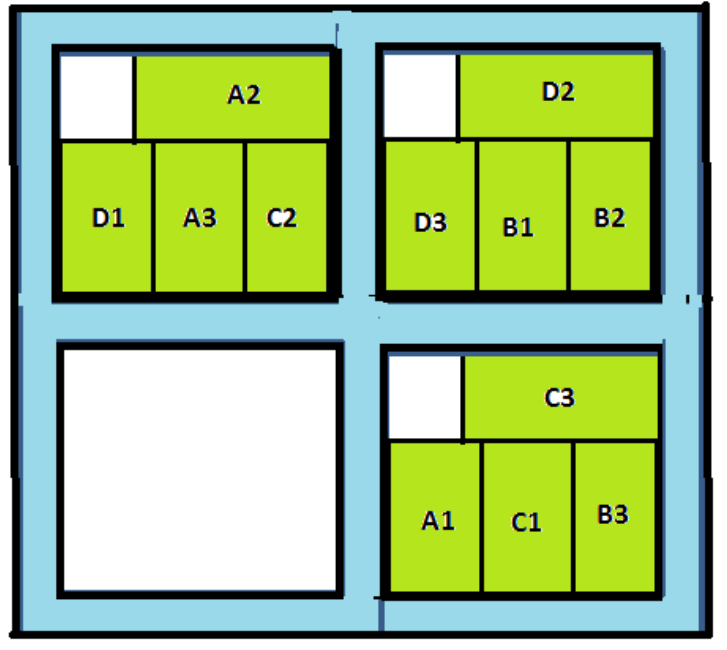

Gambar 2. Tata letak wadah percobaan

\section{Pakan Uji}

Pakan uji yang dipakai ada tiga macam yaitu, ikan rucah, ubi rebus dan pelet. Pakan yang diberikan berbentuk pasta padat. Komposisi bahan penyusun pakan dapat dilihat pada Tabel 1.

Tabel 1. Komposisi bahan penyusun pakan Uji

\begin{tabular}{|l|l|l|l|l|}
\hline \multirow{2}{*}{ Bahan Pakan (\%) } & \multicolumn{4}{|l|}{ Perlakuan } \\
\cline { 2 - 5 } & A & B & C & D \\
\hline Ikan rucah & 100 & 75 & 75 & 50 \\
\hline Ubi kayu & - & 25 & - & 25 \\
\hline Pelet T882 & - & - & 25 & 25 \\
\hline Total (\%) & 100 & 100 & 100 & 100 \\
\hline
\end{tabular}

Pemberian pakan dilakukan setiap hari dengan frekwensi 3 kali yaitu pagi, siang dan sore hari. Setiap minggu dilakukan penimbangan berat dan penambahan jumlah pemberian pakan. Data berat ikan setiap kali penimbangan digunakan untuk menghitung pertumbuhan mutlak, pertumbuhan nisbi (Effendie, 1997) dan nilai ubah pakan (Mujiman, 2008).
Untuk mengetahui pengaruh perbedaan pakan terhadap pertambahan berat ikan Kuwe dan nilai ubah pakannya dilakukan analisis ragam (Anova) dan uji lanjut BNT untuk mengetahui perbedaan pengaruh antar perlakuan (Setiawan, 2009).

\section{HASIL DAN PEMBAHASAN}

Pertumbuhan mutlak ikan kuwe dari pakan uji yang digunakan selama 7 minggu penelitian diperlihatkan pada Tabel 2. Data yang ada menunjukan bahwa penggunaan pakan uji dengan kandungan bahan yang berbeda memberikan pengaruh terhadap pertumbuhan ikan kuwe. Hal ini ditandai dengan bertambahnya berat pada akhir penelitian pada semua kelompok ikan yang menerima perlakuan. Beberapa faktor lingkungan perairan selama penelitian juga diamati dan hasilnya sebagai berikut: suhu air dengan kisaran $28-30^{\circ} \mathrm{C}$, salinitas antara 24-30 \%oo dan kecerahan 6-9,5m. Data kualitas air tersebut berada pada kisaran yang layak bagi kehidupan dan pertumbuhan ikan kuwe.

Hasil pengamatan menunjukkan bahwa tidak semua pakan yang diberikan dimakan ikan Kuwe peliharaan. Diperkirakan hampir 90\% pakan ramuan baik ikan rucah maupun pakan tambahan hancur saat diberikan dan terbuang di kolom air serta menempel pada dinding dan dasar wadah pemeliharaan. Menurut Sim $d k k$. (2005), potongan-potongan kecil ikan rucah yang terbuang selama proses pemberian pakan menjadi busuk di dasar jaring. Pembusukan ini akan menimbulkan pencemaran dan penurunan kualitas air di wadah peliharaan. 
Tabel 2. Pertumbuhan Ikan Kuwe dan Nilai Ubah Pakan

\begin{tabular}{|l|c|c|c|c|c|}
\hline \multirow{2}{*}{ Perlakuan (Pakan) } & \multicolumn{2}{|c|}{ Berat Rata-rata (g) } & \multicolumn{2}{|c|}{ Pertambahan Berat } & \multirow{2}{*}{ Rata-rata } \\
\cline { 2 - 5 } & Awal & Akhir & $\begin{array}{c}\text { Mutlak } \\
\text { (g) }\end{array}$ & Relatif (\%) & NUP \\
\hline A. Rucah & 62.9 & 285.7 & 222.8 & 354.2 & 2.80 \\
\hline B. Rucah+Ubi & 61.5 & 230.2 & 168.7 & 274.3 & 4.25 \\
\hline C. Rucah+Pelet & 62.1 & 240.1 & 178,0 & 286.6 & 3.70 \\
\hline D. Rucah+Ubi+Pelet & 60.9 & 231.7 & 170.8 & 280.5 & 3.88 \\
\hline
\end{tabular}

\section{Pertumbuhan Mutlak}

Pertumbuhan mutlak individu dari masing-masing perlakuan memperlihatkan adanya perbedaan berat yang dapat dicapai. Ikan yang menerima pakan rucah (Perlakuan A) memperoleh berat mutlak rata-rata sebesar 232,7 gram yang merupakan nilai capaian tertinggi jika dibandingkan dengan perlakuan lainnya. Penambahan bahan lain seperti ubi kayu dan pelet pada ikan rucah (Perlakuan B, C, dan D) memberikan pertambahan berat yang lebih rendah jika dibandingkan dengan penggunaan pakan rucah tanpa tambahan bahan lain. Penambahan pelet pada pakan ikan rucah (Perlakuan C) memberikan tambahan berat rata-rata 178,0 gram dan lebih tinggi jika dibandingkan dengan penambahan ubi kayu pada pakan rucah (Perlakuan B) yang hanya 168,7 gram. Penggunaan campuran ubi kayu dan pelet pada ikan rucah (Perlakuan D) memberikan pertambahan berat sebesar 170,8 gram, dianggap masih lebih baik jika dibandingkan dengan Perlakuan B (Tabel 2).

\section{Pertumbuhan nisbi}

Data pertumbuhan nisbi diperoleh dari berat yang dicapai dalam suatu periode waktu tettentu dibandingkan dengan berat awal yang dinyatakan dalam persen(\%). Persentase pertambahan berat dari setiap perlakuan yang dihitung pada setiap minggu pengamatan selama 7 minggu hasilnya dipaparkan pada Gambar 3.

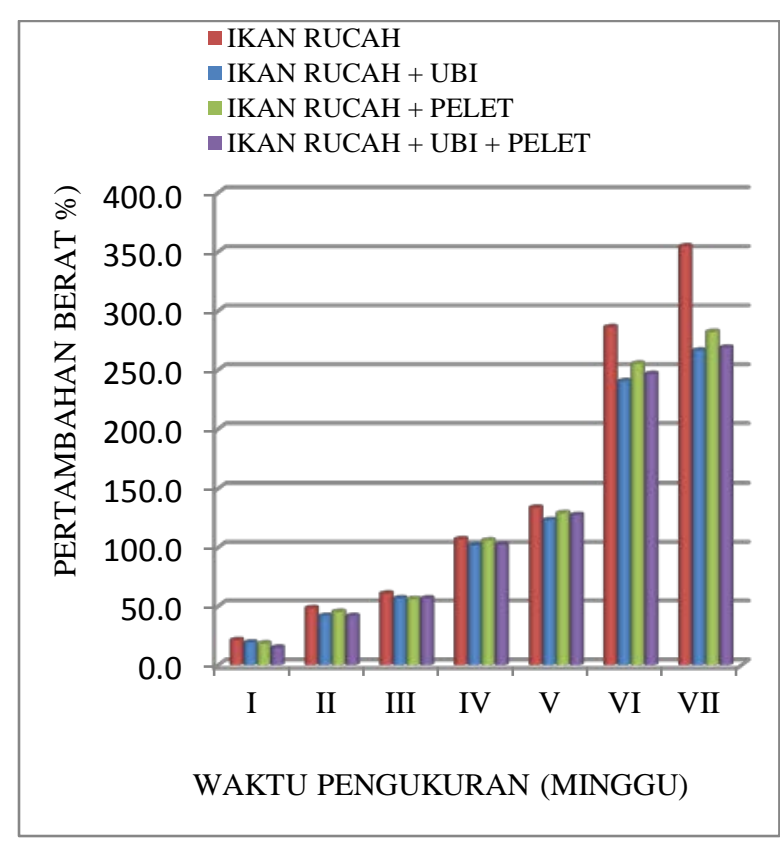

Gambar 3. Pertambahan berat ikan kuwe

Pada Gambar di atas, rata-rata persentase pertambahan berat pada setiap perlakuan masih menunjukan kondisi yang tidak berbeda sampai pada minggu ke-5, namun pada minggu berikutnya (ke-6) ikan yang diberi pakan ikan rucah (Perlakuan A) 
menunjukkan pertambahan berat lebih baik. Persentase pertambahan ini menunjukan bahwa peningkatan pertumbuhan ikan kuwe mulai terlihat setelah minggu ke-5 dan akan bertambah laju peningkatannya pada minggu ke-6 dan ke-7.

Persentase pertambahan berat akhir pada minggu ke-7 secara berturut-turut dari nilai tertinggi adalah Perlakuan Pakan rucah 354,9\%; Rucah + pelet 282,4\%; Rucah + Ubi + Pelet 269,0\% dan terendah Perlakuan Rucah + Ubi 266,6\%.

\section{Pengaruh bahan tambahan pada pakan rucah terhadap pertambahan berat}

Hasil analiss statistik Anova untuk meguji pengaruh bahan tambahan pada pakan rucah terhadap pertambahan berat ikan kuwe mendapatkan hasil bahwa nilai $\mathrm{F}$ hitung F hitung $=34,441>$ F tabel $_{0,05(3,8)}=$ 4,07, memberikan hasil bahwa ada perbedaan yang nyata pada pertambahan berat ikan Kuwe yang diberikan pakan ikan rucah dan pakan tambahan.

Hasil uji lanjut BNT pertambahan berat pada Perlakuan A menunjukkan perbedaan yang nyata terhadap ketiga perlakuan lainnya (B, C, dan D). Sedangkan ketiga perlakuan lainnya tidak menunjukkan perbedaan yang nyata. Sehingga dapat diartikan penggunaan pakan rucah tanpa bahan tambahan yang lain bahwa lebih baik jika dibandingkan dengan Perlakuan B, C, dan D yang pakan rucahnya diberi tambahan pakan lain. Karena pertumbuhannya sangat nyata. Sebaliknya pertumbuhan mutlak yang dihasilkan oleh Perlakuan B, C, dan D hasilnya tidak berbeda nyata, ini berarti bahwa penggunaan ubi kayu, pelet dan campuran ubi kayu dan pelet belum dapat digunakan sebagai bahan pengganti rucah ikan dalam menunjang laju pertambahan berat ikan kuwe.

\section{Nilai Ubah Pakan}

Nilai ubah pakan dari masingmasing perlakuan memperlihatkan adanya perbedaan hasil yang dapat dicapai (Tabel 2). Penggunaan pakan rucah (Perlakuan A) memperoleh nilai sebesar 2,80 dan merupakan nilai capaian terendah jika dibandingkan dengan perlakuan lainnya. Penambahan bahan lain seperti ubi kayu dan pelet pada ikan rucah (Perlakuan B, C, dan D) memberikan pertambahan nilai ubah pakan menjadi lebih tinggi jika dibandingkan dengan penggunaan pakan rucah tanpa tambahan bahan lain. Bahan pelet (Perlakuan C) memberikan nilai ubah pakan sebesar 3,70, jika dibandingkan dengan ubi kayu (Perlakuan B) sebesar 4,25. Penggunaan campuran ubi kayu dan pelet pada ikan rucah (Perlakuan D) memberikan nilai ubah pakan sebesar 3,88, masih lebih baik jika dibandingkan dengan Perlakuan B (pengunaan tambahan ubi kayu).

Hasil analisis ragam menunjukkan bahwa ada perbedaan nyata nilai ubah pakan ikan Kuwe di antara perlakuan pakan yang diberikan (F hitung $=45,04>\mathrm{F}$ tabel $0,05(3,8)$ $=4,07$ Hasil uji lanjut BNT meunjukkan bahwa Perlakuan A (Pakan rucah) menunjukkan perbedaan yang nyata dibandingan dengan ketiga perlakuan lainnya, perlakuan $\mathrm{B}$ berbeda nyata dibandingkan dengan perlakuan C dan D. Hasil ini mengindikasikan bahwa penggunaan pakan rucah tanpa bahan tambahan yang lain (perlakuan A) lebih baik 
jika dibandingkan dengan Perlakuan B, C, dan D karena perbedaan nilai ubah pakan yang diperoleh sangat nyata. Ini berarti bahwa penggunaan ubi kayu, pelet dan campuran ubi kayu dan pelet belum dapat digunakan sebagai bahan pengganti rucah ikan karena tidak seefisien rucah.

\section{KESIMPULAN}

Penggunaan pakan rucah pada budidaya ikan kuwe selama tujuh minggu menghasilkan pertumbuhan mutlak dan pertumbuhan nisbi terbaik dengan nilai ubah pakan terendah $(2,80)$.

\section{DAFTAR PUSTAKA}

Anonim 2009. O-Fish : Pakan ikan. Budidaya Ikan O-fish.doc.

Aziz AD. 1988. Budidaya Laut dan Kemungkinan Pengembangannya di Sulawesi Utara. Seafarming Workshop Report, Bandar Lampung 28 October - 1 November 1985. Pt. II: Technical Report. http://www. fao.org/docrep/field/003/AB882E/A B882E00.htm

Effendie M I. 1997. Metode Biologi Perikanan. Yayasan Dewi Sri. Bogor. 128 hal.

Irianto B, Zubaidi T, Hasan N, Harwanti S, Suwarda R. 2002 Potensi Pengembangan Budidaya Ikan Kuwe, Caranx spp. Dengan Sistem Keramba Jaring Apung. Balai Penelitian Perikanan Budidaya Pantai Maros. 49 hal.
Lutfillah E. 1988. Berbagai Cara Penanganan Ikan Rucah dan Pembuatan Pelet Ikan. Fakultas Teknologi Pertanian Institut Pertanian Bogor.

Mujiman A. 2008. Makanan Ikan : Pengetahuan lengkap tentang jenisjenis makanan ikan, cara memproduksinya, dan aplikasinya. Penebar Swadaya, Jakarta. 192 hal.

Randall JE, Allen GR, Steene RC. 1997. Fishes of the Great Barrier Reef and Coral Sea. University of Hawaii Press North America. 507 p

Setiawan (2009). Rancangan Acak Lengkap.

http://smartstat.wordpress.com

Sim SY, Rimmer MA, Toledo JD, Sugama $\mathrm{K}$, Rumengan I, Williams KC, Phillips MJ. 2005. Pedoman Praktis Pemberian dan Pengelolaan Pakan untuk Ikan Kerapu yang dibudidaya. NACA, Bangkok, Thailand. 18 ha.

Yudha IG. 2003. Studi pertumbuhan ikan kerapu bebek (Cromileptes altivelis ) dalam keramba jaring apung (KJA) di Pulau Puhawang, Kabupaten Lampung Selatan. Fakultas Pertanian Universtas Lampung. 13 hal. 